\title{
A questão fundiária na Amazônia
}

VIOLETA REFKALEFSKY LOUREIRO

e JAX Nildo ARAGÃo PINTO

\section{Algumas fontes para a compreensão do problema atual} A ocupação da terra até a ditadura militar

A TÉ MEADOS DOS ANOS de 1960, as terras amazônicas pertenciam basicamente à União e aos estados. Do total das terras registradas pelo IBGE $^{1}$, $87 \%$ constituíam-se de matas e terras incultas, que eram exploradas por milhares de caboclos e ribeirinhos que viviam do extrativismo vegetal e animal; $11 \%$ constituíam-se de pastos naturais onde antigos fazendeiros haviam assentado fazendas de gado, sendo muitas delas seculares, como as do Marajó, de Roraima e do Baixo Amazonas, cujos títulos de terra eram igualmente antigos. Essas poucas fazendas eram como que "ilhas" de criação de gado nos campos naturais (abundantes na região) e não em pastos formados em cima de mata derrubada ou queimada como hoje. A mata e os rios estavam preservados e eram aproveitados pelos habitantes como fonte de alimento, trabalho e vida.

Somente 1,8\% das terras estavam ocupadas com lavouras e só metade delas possuía título de propriedade privada ${ }^{2}$. A quase totalidade das terras da Amazônia era, portanto, constituída por terras públicas e "livres" de titulação como propriedade privada. Eram ocupadas por milhares de pequenos posseiros, que nelas haviam constituído seu trabalho efetivo (como extrativistas na coleta de frutos, raízes, óleos, resinas e sementes das matas, em geral exportados para os mais diversos fins - industriais, medicinais ou alimentares; ao lado disso cultivavam roçados minúsculos, plantavam pomares e hortas nos quintais e praticavam a pesca em rios e lagos). Os naturais da região habitavam essas terras secularmente, sem disputa ou conflito, assim como muitos migrantes de longa data. Viviam uma vida frugal, modesta, pacífica e cuja monotonia era quebrada pelas raras festividades de santos. Os moradores da região consideravam a terra como parte indissociável de suas existências, tendo habilitado nelas por gerações seguidas, sem se terem jamais questionado sobre a existência de donos mais legítimos que eles próprios.

\section{Transformações e conflitos fomentados pelo próprio Estado na Amazônia}

Durante os anos de 1960 e 1970, os principais obstáculos ao desenvolvimento dos países periféricos e de regiões atrasadas economicamente como a Amazônia eram atribuídos a dois problemas básicos: à insuficiência de capitais produtivos e de infra-estruturas capazes de pôr em marcha novos investimentos $^{3}$. Na época, essas e outras teorias com enfoques semelhantes entendiam que seria possível atrair capitais produtivos, organizados sob a forma de conglomera- 
dos econômicos, vindos de outros pontos do Brasil e do exterior, desde que fossem oferecidas vantagens capazes de atrair esses capitais para a região. Assim, o novo modelo de desenvolvimento para a Amazônia - posto em prática pelos governos militares pós-1964 para desenvolver e integrar a região ao mercado nacional e internacional - inspirava-se nessas concepções teóricas, feitas as adaptações que os militares e a tecno-burocracia julgaram conveniente fazer para aquele momento da ditadura.

A proposta baseava-se em oferecer inúmeras vantagens fiscais a grandes empresários e grupos econômicos nacionais e internacionais que quisessem investir novos capitais nos empreendimentos que viessem a se instalar na região. Seu principal instrumento eram os incentivos fiscais, reorientados legalmente em 1967, principalmente para a pecuária, a extração madeireira, a mineração, atividades que, simultaneamente, requerem grandes quantidades de terra, destinam-se à exploração de produtos primários ou semi-elaborados e geram poucos empregos. Eram concedidos (via Sudam e Basa) aos empresários por longos períodos (dez a quinze anos). Por meio dos incentivos fiscais, as grandes empresas beneficiadas poderiam destinar uma parte ou até a totalidade do imposto de renda que deveriam pagar ao governo, para criar com aqueles recursos novas empresas na região. Além disso, o governo ainda disponibilizava recursos financeiros a juros muito baixos e até negativos e concedia um sem-número de outras facilidades. Dessa forma, o Governo Federal abriu mão do dinheiro com o qual poderia modernizar as atividades tradicionais dos pequenos e médios produtores da região ou para investimentos sociais, como escolas, hospitais etc.; preferiu transferir esses recursos para grandes empresas.

Muitos empresários não investiram os recursos em novas empresas na região, mas sim na compra de terras para simples especulação futura; alguns aplicaram-nos em suas empresas situadas noutras regiões do país; e várias empresas foram criadas de forma fictícia. Outras (como a Volkswagen, o Bamerindus etc.) devastaram grandes extensões de terras cobertas por ricas florestas e transformaram essas áreas em pasto para a criação de gado, desprezando a enorme disponibilidade de pastos e campos naturais; enfim, trouxeram grandes prejuízos ecológicos, desperdiçaram ou desviaram os recursos públicos colocados à sua disposição, criaram poucos empregos e não trouxeram o prometido desenvolvimento para a região. Ainda assim, o modelo permanece até hoje sem grandes alterações, apesar do fracasso notório dessa política, seja do ponto de vista ambiental, econômico ou social ${ }^{4}$.

As facilidades legais concebidas para atrair empresários estimulavam o acesso a grandes extensões de terra e à natureza em geral. Para transferir a terra pública (devoluta $)^{5}$ para os grandes grupos econômicos e garantir a propriedade da terra aos pretensos investidores futuros, o governo alterou a legislação existente e criou dispositivos legais extraordinários e de exceção.

Além disso, o Governo Federal oferecia garantia de infra-estruturas para os novos projetos (estradas, portos, aeroportos e outros). Às margens das estradas, 
a devastação florestal foi rápida e a disputa de terras privilegiadas às margens delas gerou, desde o fim dos anos de 1960, conflitos de toda ordem, que só foram aumentando nas décadas seguintes, à medida que o modelo de desenvolvimento se estruturava. Comprometeu-se ainda o Governo Federal em trazer mão-de-obra barata de outros pontos do Brasil (nordestinos que fugiam da seca, em especial), para atuar nas frentes de trabalho (abertura de estradas, desmatamento, construção de portos, aeroportos etc.). Esses milhares de trabalhadores, após concluídas as obras, ficaram na região em busca de terra e das oportunidades de trabalho que, de qualquer forma, lhes pareciam ser - na Amazônia -, mais promissoras do que aquelas que já conheciam e haviam enfrentado em suas terras de origem. A população da Amazônia ${ }^{6}$, que era de 2.601.519 habitantes em 1960, havia ascendido a 4.197.038 em 1970.

\section{Grilagem e conflito convertem-se em práticas no cotidiano da região}

Se a concentração de renda provocada pela política de incentivos era por si só danosa para a região (já que beneficiava apenas os grandes grupos econômicos nacionais e estrangeiros), o dano maior, entretanto, estava ligado à questão da terra. Nos anos de 1970 e 1980, a terra pública, habitada secularmente por colonos, ribeirinhos, índios, caboclos em geral, foi sendo colocada à venda em lotes de grandes dimensões para os novos investidores, que as adquiriam diretamente dos órgãos fundiários do governo ou de particulares (que, em grande parte, revendiam a terra pública como se ela fosse própria). Em ambos os casos, era freqüente que as terras adquiridas fossem demarcadas pelos novos proprietários numa extensão muito maior do que a dos lotes que originalmente haviam adquirido.

Desde os anos de 1960, tornaram-se comuns certas práticas que ainda hoje ocorrem objetivando a grilagem de terras, tais como: a venda de uma mesma terra a compradores diversos; a revenda de títulos de terras públicas a terceiros como se elas tivessem sido postas legalmente à venda através de processos licitatórios; a falsificação e a demarcação da terra comprada por alguém numa extensão muito maior do que a que foi originalmente adquirida, com os devidos documentos ampliando-a; a confecção ou adulteração de títulos de propriedade e certidões diversas; a incorporação de terra pública a terras particulares; a venda de títulos de terra atribuídos a áreas que não correspondem aos mesmos; a venda de terra pública, inclusive indígena e em áreas de conservação ambiental, por particulares a terceiros; o remembramento de terras às margens das grandes estradas federais, que em anos anteriores haviam sido distribuídas em pequenos lotes para fins de reforma agrária a agricultores e a posterior venda dos lotes, já remembrados, transformando-os em grandes fazendas de gado; e ainda, mais recentemente, a venda de terra pública pela internet como se os vendedores fossem seus reais proprietários, com base em documentação forjada.

Como nos anos de 1970 e 1980 não estavam ainda disponíveis imagens de satélite para demarcar mais precisamente os limites ou identificar a existência de famílias dentro das áreas a serem adquiridas pelos novos compradores, os lotes 
eram demarcados e cercados com os antigos moradores dentro deles. Os órgãos fundiários também não solicitavam do pretendente à compra qualquer documento da prefeitura, dos sindicatos de trabalhadores rurais, das igrejas ou de qualquer outra fonte para comprovar a inexistência de antigos moradores nas terras postas à venda. Assim, foram vendidas terras com moradores seculares habitando nelas. E a concentração da terra na Amazônia alcançou níveis intoleráveis que foram sendo revidados, cada vez mais, sob a forma de conflitos. No Mato Grosso, por exemplo, uma única empresa, a Suiá Missu consegue adquirir 695.843 ha; no Pará somente oito grupos econômicos possuíam quase seis milhões de hectares ${ }^{7}$.

Somente quando os novos proprietários começavam a queimar a mata para formar pastos ou derrubá-la para vender a madeira, os antigos moradores se deparavam com o fato de que as terras em que moravam haviam sido vendidas, em geral para grandes sociedades anônimas, cujos proprietários habitavam fora da região. A expulsão dos moradores tornava o conflito uma prática cotidiana. Como as terras pertenciam, por posse imemorial aos antigos moradores, o governo encontrou um mecanismo para regularizá-las e criou condições que permitiam ao novo proprietário se apropriar da terra numa extensão muito maior do que aquela que fora realmente adquirida. A concentração fundiária daquelas décadas permaneceu praticamente inalterada até hoje. Da mesma forma, a maior parte da terra grilada transformou-se em situações consolidadas.

Os novos empresários, especuladores e aventureiros, procedentes de diversos rincões do país e do exterior, adquiriram imensas áreas. Surge aí a figura do "grande posseiro", como se auto-intitula o "grileiro". No Pará, por exemplo, a grilagem de grandes áreas é contestada pelo Ministério Público ou por entidades diversas que, na Justiça, tentam reverter o quadro originado nos anos anteriores e que persiste até os dias atuais.

$\mathrm{Na}$ Amazônia, os direitos humanos, durante décadas, estiveram subordinados aos direitos do capital e muitas situações acabaram se cristalizando. Durante mais de vinte anos esses problemas acumularam-se sem solução, a não ser em casos pontuais e após conflito seguido de morte. Nesse período, a terra pública transformou-se, por meios legais, fraude ou grilagem, em terra privada.

Nos anos de 1990, devido às políticas neoliberais implantadas no país e à conseqüente contenção dos orçamentos dos órgãos fundiários, as ações discriminatórias de terra tornaram-se raras na Amazônia ${ }^{8}$. A terra pública continuou confundindo-se, por meios lícitos ou não, com a terra privada, aumentando o caos fundiário das décadas anteriores e tornando cada vez mais difícil reconhecer e separar a terra pública da privada.

\section{Interessado em privatizar a terra pública, o Estado aceitou conviver com a grilagem}

Como o Estado permitiu a legitimação e a legalização da grilagem de terras na Amazônia? Para tornar legal a aquisição de terra demarcada ou comprada 
fraudulentamente, muitas delas já aquinhoadas com incentivos fiscais, o Governo Federal regularizou (por meio das Medidas Provisórias 005 e 006, de 6/6/ 1976 da Casa Militar da Presidência da República) as terras griladas e deu à Justiça os instrumentos legais de que esta precisava para legalizá-las e, posteriormente, promover a expulsão dos antigos moradores. Diz o texto legal "permitese a regularização de propriedades de até 60 mil ha que tenham sido adquiridas irregularmente mas com boa fé". A Exposição de Motivos assim justifica a criação das medidas: "Esses projetos, mesmo à revelia da lei e da ordem se redimem por seus resultados, na medida em que promoverão o desenvolvimento da região". Portanto, o próprio Estado autorizou a grilagem na região e instituiu-a como uma prática tolerável, não só legitimando-a como legalizando-a; e reforçou-a ao conceder empréstimos e financiamentos para investir nas terras. Os diversos estados da região amazônica acompanharam a medida federal criando leis estaduais que também legitimaram a compra de terras griladas ou adquiridas de forma irregular. $\mathrm{E}$ as conseqüências desses atos permanecem até hoje.

Apesar das facilidades, muitos dos novos investidores, não tendo sequer a precária documentação exigida para ocupar a terra, dispensavam financiamentos; eram (e alguns são) simplesmente aventureiros que implantavam (e implantam) empreendimentos madeireiros e que, após extraírem a madeira que lhes interessa, vendem as terras - que não lhes pertencem - para criadores de gado ou para a extração de minérios.

As áreas pleiteadas por grileiros, madeireiros e criadores de gado eram habitadas por centenas de famílias de colonos que nelas viviam e seus direitos à terra, apesar de contestados junto à Justiça ou por confronto direto, estavam amparados legalmente: os naturais da região já estavam na terra há algumas décadas e nelas se haviam estabelecido com posse mansa e pacífica, trabalho efetivo e morada habitual, portanto, na forma da lei ${ }^{9}$. As Medidas Provisórias aceleraram a legalização da fraude e da grilagem e intensificaram os conflitos. A Constituição de 1988 ignorou questões como essas e o caos fundiário acabou se consolidando. O que se constata é que o conflito de terras resulta da ação elitista, excludente e desastrada do Estado durante décadas na Amazônia.

\section{Os direitos humanos e os direitos do capital}

Essa permanente política de exclusão movida pelo Estado em relação aos pobres do campo é revidada sob a forma do conflito por colonos, ribeirinhos e migrantes expulsos de suas terras. Mesmo considerando que isto ocorresse por meio de atos legalmente acobertados por documentos criados naquele momento histórico, estes não eram considerados legítimos do ponto de vista social e dos direitos humanos fundamentais.

Da mesma forma e pelos mesmos instrumentos legais estavam amparados os antigos migrantes nordestinos que haviam chegado para as construções das primeiras estradas, como a Belém-Brasília, nos anos de 1950 ou até em épocas anteriores, alguns deles desde o período da borracha. Contudo, a Justiça reco- 
nheceu os papéis validados pelas Medidas Provisórias e outros instrumentos de exceção da ditadura, garantindo a expulsão de antigos e legítimos posseiros e estimulando os conflitos e a violência na região.

Além disso, era comum que diversos membros de uma mesma família ou que empresas diferentes de um mesmo grupo econômico regularizassem vários lotes de terra. Por mecanismos diversos, a concentração de terras assumiu enormes proporções e as expulsões tornaram-se cada vez mais violentas, porque se encontravam agora respaldadas por dispositivos legais que mobilizavam contingentes policiais, sob ordem judicial, para desalojar os posseiros. Assim, os conflitos passaram a ser o procedimento pelo qual muitos dos novos proprietários assumiam a terra comprada ou grilada.

Desenvolveu-se durante a ditadura uma convivência estreita de interesses e até uma conivência entre grileiros-empresários-aventureiros e órgãos públicos, especialmente os federais com ação na região. Esta espúria aliança entre setores/ órgãos/ funcionários do Estado com empresários/ aventureiros/grileiros sobreviveu à ditadura, e é hoje, parte de muitas das relações políticas e econômicas na região. Eram e ainda são comuns casos de funcionários públicos que "esquentavam" documentos forjados com vistas à regularização e à legalização de terras griladas. Jornais, relatórios e revistas denunciam esta aliança à larga e publicamente, a qualquer momento que sejam consultados ${ }^{10}$.

Para o Ibama, responsável pela política de combate aos crescentes desmatamentos na Amazônia, sobra a acusação de ter utilizado aviões pertencentes ao empreiteiro Cecílio do Rego Almeida para fazer operações de retirada de madeireiras ilegais na Terra do Meio, entre os vales do Xingu e Tapajós. Nada de anormal na cessão de aeronaves se Almeida não fosse, ele próprio, o responsável pela maior grilagem de terras na Amazônia, numa área superior a cinco milhões de hectares, maior do que o estado de Sergipe, localizada justamente na Terra do $\mathrm{Meio}^{11} \ldots$

A Constituição de 1988 não conseguiu democratizar e nortear minimamente a questão agrária e fundiária nacional, muito menos a amazônica, pois para fazê-lo seria necessário retirar "os esqueletos do armário" e reviver um momento histórico difícil e traumático. Também não criou instrumentos concretos e rigorosos que desestimulassem a fraude ligada à terra, a ação das milícias privadas que se haviam criado naqueles anos e ainda existem, ou o trabalho escravo (que, quase sempre, vem sendo considerado como um problema trabalhista e não como violação de direitos humanos). Voltou-se mais diretamente para os direitos individuais e políticos que haviam sido violados pela ditadura; mas a questão social amazônica permaneceu intocada, assumindo contornos cada vez mais graves.

O quadro social da região havia se agravado face à prolongada recessão brasileira dos anos de 1980, provocando um vigoroso e descontrolado processo migratório de brasileiros procedentes de outros pontos do país para a Amazônia, buscando aí melhor oportunidade de trabalho e vida. 
Esses migrantes pobres começaram a ocupar as terras ociosas, especialmente aquelas que apresentavam evidências de fraude na cadeia dominial; as terras onde os incentivos fiscais não haviam sido aplicados; ou terras excessivamente extensas que estavam parcial ou totalmente inaproveitadas, mas que se localizavam às margens de estradas e rios. Ao chegar, uma parte dos migrantes trabalha na derrubada da mata, em garimpos (em terra indígena ou não). Outros cultivam pequenos lotes utilizando processos que, face ao expressivo número de migrantes pressionando os recursos naturais da região, também tornaram-se danosos à natureza: em geral, trocam a madeira nobre existente no lote por uma precária picada de terra aberta pela madeireira para que, através dela, alcancem a estrada para a venda da produção; queimam e plantam algumas poucas safras e (como as terras amazônicas ao ficarem desprotegidas de sua cobertura florestal empobrecem rapidamente), esses posseiros vendem a terra ocupada a terceiros e saem em busca de outras.

Os novos compradores vão remembrando os pequenos lotes, "esquentando a documentação" e formando áreas maiores que são revendidas a futuros criadores de gado ou a simples especuladores da terra. E o processo recomeça sem cessar. Mas as maiores queimadas não têm origem nos lotes dos pequenos colonos e sim nas grandes fazendas (após a retirada da madeira nobre), formadas em terras compradas ou griladas. De uma forma ou de outra, em pequenas ou grandes extensões os desmatamentos aumentam sempre. E assim, em pouco mais de trinta anos (de 1970 a 2004), conforme estimativa do Inpe (Instituto Nacional de Pesquisas Espaciais), em torno de 17\% das terras amazônicas já se encontram profundamente alteradas. E o processo não apresenta qualquer tendência a diminuir.

\section{Tolerância e convivência do Estado com a pistolagem}

A pistolagem, fenômeno que começou também a integrar o cotidiano de ocupação da terra, é algo recente na Amazônia, datando de mais ou menos trinta anos. Mas, não só neste aspecto o pistoleiro da Amazônia difere do cangaceiro e do capanga do nordeste. Ele tem uma origem histórica e social diferente da deles e possui uma natureza também própria. O pistoleiro surge na região para proteger contra invasão (por parte de posseiros) as grandes extensões de terras adquiridas mas ociosas ou improdutivas. Um pistoleiro pode ser contratado para expulsar colonos que as ocuparam; para assassinar lideranças e sindicalistas. Ou ainda, para "ajudar" nas ações policiais de despejo de posseiros. Como o contingente policial era, e ainda é insuficiente para cumprir ordens de mandado emanadas da Justiça, alguns fazendeiros inseriam pistoleiros nos contingentes policiais encarregados da expulsão.

Sob o olhar conivente e tolerante do Estado empresas e grileiros formaram milícias privadas, a que chamam de "vigilância" ou "segurança", montadas para garantir a posse e a defesa da terra nas distantes terras amazônicas. Assim, estabeleceu-se na região um compartilhamento de objetivos comuns entre fa- 
zendeiros interessados nas terras, autoridades que ignoravam a participação das milícias privadas de defesa das fazendas, políticos beneficiados com terras e a pistolagem.

Após a ditadura, o Estado não conseguiu mais recuperar para si o poder de polícia que, informalmente, havia antes delegado ou repartido com os fazendeiros da região para ajudarem a "por ordem" nas questões fundiárias e nos conflitos delas decorrentes. A origem central da pistolagem na Amazônia, no nosso entendimento, é clara: decorre da repartição do poder do Estado com os integrantes, defensores e prepostos do novo capital que se instalou desordenadamente na região desde os anos de 1970.

O Estado tolerou durante várias décadas esta divisão do poder de polícia, ignorando ou à revelia das denúncias da $\mathrm{OAB}$, da Comissão Pastoral da Terra e de outras organizações sobre a participação de pistoleiros nessas polícias privadas. Esta prática flagrante de violação dos direitos humanos mais elementares enraizou-se nas relações sociais e políticas da região. Hoje, o Estado procura retomar o controle desta situação que envergonha a sociedade brasileira, mas tem dificuldade em dominar esta anomalia que ele próprio deixou crescer.

De acordo com Max Weber ${ }^{12}$, o Estado moderno, ao se constituir, foi retirando dos diversos elementos da sociedade o direito de uso da força e da violência que antes era exercido por várias instâncias sociais, e foi concentrando para si este direito, utilizando-o apenas de conformidade com as leis vigentes. Hoje, o Estado moderno reivindica para si "o monopólio da violência física legítima”, exercendo-o como o seu único detentor. E o uso da força e da violência pelo Estado é legítimo porque está fundado em lei socialmente reconhecida. Só o Estado detém a autoridade e o poder de prender, de sustar o direito de ir e vir e de algemar e punir o cidadão de várias formas. Mas na Amazônia o Estado repartiu este poder com empresários, políticos e aventureiros os mais diversos, perdendo o controle sobre o exercício da força e da violência física, que passou a ser usada por agentes não legitimados socialmente nem legalmente instituídos. Hoje, o Estado não consegue administrar a situação e recuperar para si o poder que, indiretamente, delegou para certos agentes. Assim, a pistolagem transformou-se num grave componente da questão agrária regional.

\section{Um modelo de desenvolvimento(!) fundado na exploração predatória da natureza}

Quando se analisa a pauta de exportação da região norte nos anos de 1950 e 1960, observa-se que a base da economia estava fundada na exportação de produtos primários. Somente o manganês do Amapá correspondia a $62 \%$ da pauta e este, somado à castanha do pará (28\%) totalizava $90 \%$. Os demais produtos eram a pimenta-do-reino, os couros e peles de animais silvestres, as borrachas e resinas e alguns outros produtos. A madeira era um produto residual (1\%), já que a inexistência de estradas tornava difícil a exploração e a exportação da mesma ${ }^{13}$. 
A partir de 1970, vão dominando crescentemente as madeiras e a criação de gado para os mercados interno e externo. Ora, ambas as atividades, quando praticadas de forma desordenada como na Amazônia, são altamente predatórias da natureza e exigem grandes extensões de terra. Como os produtos dessas duas atividades são exportados para o mercado interno e para exterior sob a forma de semi-elaborados, ambas geram poucos empregos. Além disso, para se implantarem, foram desalojando milhares de famílias que antes viviam como ribeirinhos nas terras hoje ocupadas por esses fazendeiros e madeireiros (grileiros ou não). E mais, a internalização de renda na região é baixa, justamente porque os produtos não recebem beneficiamento industrial e a concentração de renda em ambas as atividades é elevada.

Desde os anos de 1980 eram já do conhecimento oficial, por meio de relatórios e pesquisas rigorosos, o fato de que (mesmo sem se considerar os efeitos perversos na esfera social e ambiental), os recursos adquiridos através de incentivos fiscais pela maior parte dos empresários beneficiados tinham tido destinação diferente da que se propunham. Muitos projetos eram inoperantes, improdutivos ou estavam sob condição irregular ${ }^{14}$. Na época, um estudo detalhado do Instituto de Pesquisa Econômica Aplicada (Ipea) já evidenciava que, dos 959 projetos incentivados até 1985 (dos quais 628 eram agropecuários), apenas 459 estavam operando (os demais estavam desocupados, abandonados ou não implantados, sendo as terras objeto de ocupação por migrantes). Menos de dez eram bem administrados. O procedimento tolerante do Estado em não apurar transgressões legais e "crimes de colarinho branco" como estes criou na região uma conivência perniciosa entre o público e o privado.

E a situação tende a se agravar por vários motivos: o asfaltamento da rodovia Santarém-Cuiabá não parece estar sendo antecipado e acompanhado de um conjunto de medidas visando a sustar a crescente grilagem de terras nas marginais da estrada; o plantio de soja no Pará teve início sobre áreas já degradadas do nordeste paraense mas, atualmente, vem se expandindo sobre áreas de florestas do oeste que são desmatadas (próximas de Santarém) ${ }^{15}$; é crescente e acelerada a ocupação e o desmatamento em áreas de conservação ambiental, assim como em terras indígenas. Como decorrência disso, dá-se o empobrecimento da floresta, com efeitos negativos sobre a caça e a pesca, de que antes os índios sobreviviam. Começam a aparecer na região índios miseráveis e desnutridos.

A história recente das estradas na Amazônia já proporcionou experiências negativas suficientes para que se aprenda com elas a evitar que o esperado asfalto daquela rodovia não aguce, ainda mais, a já conturbada questão agrária, fundiária e ambiental da região. Mas essa preocupação parece não estar presente nos quadros dos governos ou das classes empresariais.

\section{Por que o Pará é o estado mais afetado pelos conflitos de terra?}

O Pará carrega alguns tristes títulos, como o de campeão dos conflitos de terra e de mortes neles. De fato, nos últimos dez anos, os números relativos aos 
conflitos, mortes e ameaças de morte são excessivamente elevados, conforme se vê na tabela a seguir apresentada.

Conflitos de terra, assassinatos e ameaçados de morte no Pará - 1994-2003

\begin{tabular}{l|c|c|c|c|c|c|c|c|c|c|c|c}
\hline & 1994 & 1995 & 1996 & 1997 & 1998 & 1999 & 2000 & 2001 & 2002 & 2003 & 2004 & TOTAL \\
\hline $\begin{array}{l}\text { Conflitos } \\
\text { de terra }\end{array}$ & 35 & 38 & 63 & 60 & 37 & 86 & 53 & 115 & 110 & 136 & 104 & 837 \\
\hline Assassinatos & 12 & 14 & 33 & 12 & 12 & 9 & 5 & 8 & 20 & 33 & 15 & $\mathbf{1 7 3}$ \\
\hline $\begin{array}{l}\text { Ameaçados } \\
\text { de morte }\end{array}$ & 42 & 54 & 24 & 29 & 11 & 36 & 17 & 46 & 78 & 61 & 103 & $\mathbf{5 0 1}$ \\
\hline
\end{tabular}

Fonte: Comissão Pastoral da Terra-Pará.

A responsabilidade deste quadro é histórica e deve ser repartida. De 1971 em diante, o Governo Federal instituiu a prática de confiscar áreas de terras dos estados amazônicos e colocá-los sob a esfera federal. Isso era feito por decretos presidenciais, sem aviso prévio aos governos estaduais ou indenização posterior. Ocorreu porque o Governo Federal considerou essas terras como sendo necessárias “à segurança e ao desenvolvimento". Por meio do Decreto Federal no 1164 , de 1971, o Governo Federal retirou dos estados as terras situadas dentro de uma faixa de $100 \mathrm{~km}$ de cada lado de todas as estradas federais existentes, em construção ou simplesmente projetadas e não iniciadas. O processo ficou conhecido como a "federalização das terras amazônicas".

Como o Pará era o estado mais cortado por estradas federais, foi o mais penalizado com a medida. Por causa disso, e desde então, apenas 30\% das terras do estado do Pará ficaram sob a jurisdição do Governo do Estado $^{16}$. Os outros estados amazônicos, onde a existência de estradas federais era menor, foram menos afetados pelas medidas ${ }^{17}$. Não se pense, contudo, que, na época, houve, por parte dos estados da Amazônia, qualquer reação negativa (declarada) a essa política de confisco e de distribuição de terras. A reação pública dos estados veio somente após a ditadura.

As terras confiscadas foram destinadas a várias finalidades: venda, implantação de grandes projetos, alguns projetos de colonização oficial ${ }^{18}$ etc. E nesse processo de federalização por decreto-confisco, que se prolongou por duas décadas e que depois não foi revertido, não resta a menor dúvida de que não foram os pequenos produtores rurais os beneficiários dos programas para os quais a terra havia sido confiscada. Mesmo tendo perdido imensas áreas de terra e ficado com jurisdição sobre áreas reduzidas, os estados amazônicos continuaram a vender lotes de suas áreas restantes. Terras eram vendidas em grandes lotes sem a menor precisão ou cuidado cartográfico, sem plano de ocupação, com total desrespeito às condições ambientais e a partir de mapas confeccionados pelos interessados. E eram eles próprios, também, que demarcavam as terras adquiridas, acrescentando a elas outras áreas que, salvo algumas exceções, jamais foram conferidas. Mi- 
lhões de hectares foram vendidos a preços que giravam em torno de U\$1 a 20 dólares o hectare, valor pelo qual jamais foi oferecido um pequeno lote a um colono. Mas era o preço pelo qual os grupos econômicos adquiriam imensos lotes de terras.

E tal como na época das sesmarias da era colonial, a terra pública foi vendida a preço de banana e permaneceu estagnada, improdutiva. Pior que isto: por não dispor de um tosco mapa cadastral fundiário (que ainda ao iniciar o século XXI não tem), o governo do Pará alienou terras superpostas a títulos de posse, definitivos e de aforamentos, bem como áreas mansa e pacificamente apossadas, mas cujos sítios o Estado não sabia (como ainda não sabe) localizar ${ }^{19}$.

Mas, apesar do insucesso que o processo de licitação de terras públicas tem trazido sob todos os aspectos, ele continuou e é freqüente até hoje, embora não possa mais contar com um grande estoque de terras.

Mesmo os projetos de colonização criados às margens das estradas fracassaram e foram recomprados por grileiros e fazendeiros e remembrados em grandes fazendas. Trata-se de um processo perverso pelo qual o Estado brasileiro tem historicamente produzido, sem cessar, a miséria social, por mecanismos legais e administrativos que promovem exclusão das classes desfavorecidas num extremo, e a concentração da riqueza por grupos econômicos e setores da elite.

Em 1986, foi extinto o Gebam ${ }^{20}$, em 1987, o Getat ${ }^{21}$ e, finalmente, no segundo semestre de 1987, foi revogado o Decreto $\mathrm{n}^{\circ}$ 1164, que havia confiscado áreas marginais das rodovias federais na Amazônia legal. A revogação dos dispositivos legais da ditadura não solucionou o problema do confisco por eles gerado porque os decretos que os extinguiram mantiveram as situações já consolidadas. E assim, as terras também não foram devolvidas aos estados de origem. A questão foi simplesmente abandonada pelo Governo Federal. Como os estados não podiam atuar nessas áreas e como as situações consolidadas foram mantidas, os problemas fundiários e os conflitos de terra agravaram-se enormemente. Ao Decreto-lei no $1.164 / 71$ outros se sucederam até 1990 com o mesmo objetivo: a transferência das terras na Amazônia (como no caso do Programa Grande Carajás), seja para a iniciativa privada, seja para empresas estatais federais). As transferências foram processadas com abuso de poder e menosprezo por princípios democráticos elementares. Ao lado disso, o processo criou um caos documental e cadastral.

A Constituição do Estado do Pará de 1989 previa a revisão de todas as concessões de terras estaduais realizadas entre 1962 e 1987, mas isto não ocorreu. O Decreto-lei estadual no 271/1995 estabelece a revisão de todas as concessões feitas a partir de 1994, o que deixa de fora as décadas de maior incidência de concessões abusivas e da grilagem. De outro lado, os cadastros de terras estaduais e os diversos cadastros federais (Incra, Ibama, Funai etc.) jamais foram compatibilizados. Disso resulta que inúmeros processos tramitam em instâncias administrativas e jurídicas diferentes sem a menor possibilidade de se valerem de infor- 
mações comuns, que estejam acessíveis às diversas partes envolvidas ou interessadas nas disputas judiciais e nos conflitos. Questões arrastam-se na justiça por anos e até décadas porque, de um lado, a legislação e os documentos administrativos conferidos durante a ditadura sobre a terra foram validados e, de outro, porque a história elitista e excludente do Estado brasileiro tem considerado as mortes no campo como um problema menor. Quanto à grilagem em terras federais, igualmente pouco ou nada foi feito. A indiferença do poder público à má sorte dos trabalhadores sem-terra, a aliança e a tolerância do Estado com os abusos do capital, da elite ou dos desclassificados sociais que se instalaram na região, geraram a concentração de terras, a exclusão social, a desigualdade, a descrença no poder público e fomentaram os conflitos e a violência hoje existentes na região.

O fato de que se trata, também, do estado que registra o maior índice de impunidade pelos crimes praticados nos conflitos de terra merece estudos específicos no âmbito da sociologia jurídica. Os autores deste trabalho apenas apresentam dados sobre a matéria, dado que o tema foge à sua competência. Nos últimos 33 anos, houve 772 assassinatos no campo no Pará, com a realização de apenas três julgamentos de mandantes dos crimes: o caso exemplar do líder rural e poeta Expedito Ribeiro, cujo condenado, Jerônimo Alves de Amorim, cumpre, lamentavelmente, a sentença em prisão domiciliar em sua confortável residência em Goiânia; no caso do assassinato de João Canuto (que teve também dois familiares igualmente assassinados), mesmo condenados, os mandantes do crime há dois anos recorrem da sentença em liberdade, de forma que o processo permanece no Tribunal de Justiça do Estado aguardando solução; no caso de Eldorado de Carajás os dois comandantes da operação policial foram condenados, Coronel Pantoja e o Major Oliveira, estando presos em cela especial de um presídio militar.

Impressiona também o fato de que, mesmo nesses crimes em que houve julgamentos, as ações judiciais só foram possíveis depois de longos anos de luta, pressão e denúncias das entidades de direitos humanos nacionais e internacionais. Isto evidencia, claramente, a morosidade da justiça paraense, calcada em empecilhos nas comarcas do interior e da capital onde, ao que tudo indica, fica sujeita à pressão do poder político e econômico, que acaba retardando ou influenciando no andamento dos processos e dos julgamentos.

Processos exemplares que apuram o assassinato de lideranças e chacinas de trabalhadores rurais permanecem em comarcas do interior, sem qualquer previsão dos acusados irem a júri, tais como: o assassinato do advogado Gabriel Pimenta, em Marabá - 24 anos; a chacina de oito trabalhadores na Fazenda Ubá, em São João do Araguaia - vinte anos; a chacina de cinco trabalhadores na Fazenda Princesa, em Marabá - dezenove anos; o assassinato do sindicalista Braz, no Rio Maria quinze anos; o assassinato do sindicalista Arnaldo Delcídio, em Eldorado de Carajás doze anos; o assassinato de Onalício Barros e Valentim Serra em Parauapebas sete anos. Se o Tribunal de Justiça do Pará promete levar o caso da freira Dorothy 

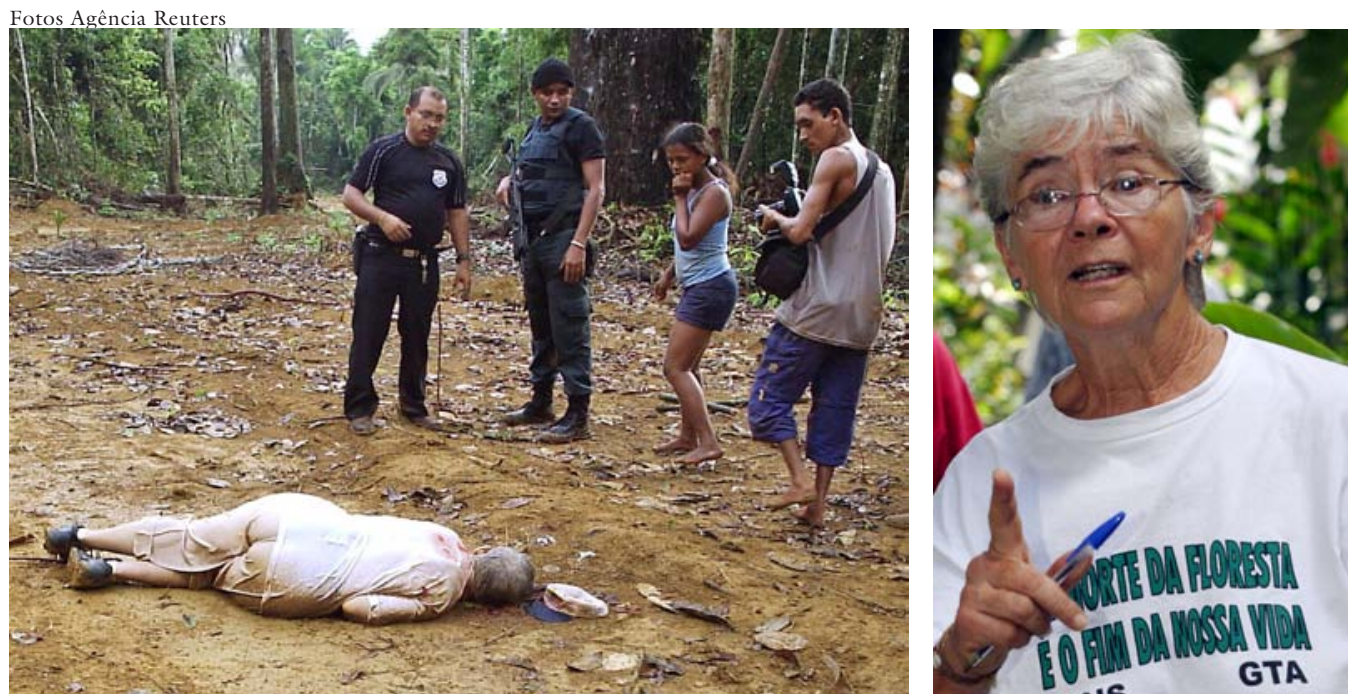

O corpo da missionária norte-americana Dorothy Stang depois de seu assassinato brutal por pistoleiros a mando de fazendeiros em 12 de fevereiro de 2005, em Anapu, no Pará.

Stang ${ }^{22}$ a júri em seis meses, como explicar a lentidão ou o abandono de outros casos exemplares? Acrescente-se ainda que no processo do assassinato de Expedito Ribeiro, três juízes abandonaram o caso e se negaram a presidir o júri e que, também no caso Eldorado do Carajás, juízes da capital designados para o caso negaram-se a presidir o julgamento, alegando "razão de foro íntimo".

O Pará é ainda o estado com a maior incidência de trabalho escravo e o segundo com maior índice de grilagem de terra. É bem verdade que alguns desses tristes títulos têm sua raiz na história recente da Amazônia e do Pará, mas persistem até hoje, dado que o Estado brasileiro não assumiu, séria e eficazmente, a responsabilidade e o empenho de combatê-los e de puni-los. O trabalhador escravo, geralmente nordestino, desconhecendo completamente a geografia da região, quando contratado para o corte de madeira ou para desmatamentos seguidos da formação de pastos em fazendas, torna-se uma presa fácil dos "gatos" 23 porque não sabe em que ponto da região se encontra, não sabe como fugir, nem tem meios para fazê-lo e é vigiado constantemente.

A dimensão, a violência e a freqüência dos conflitos de terra hoje em curso na região são desconhecidas por amplos setores da sociedade brasileira. $\mathrm{O}$ caos fundiário e as disputas dele decorrentes são questões que o Estado brasileiro omite, obscurece ou minimiza (na medida do possível), porque elas fazem parte de um mundo distante, pioneiro e "selvagem" - o interior da Amazônia.

\section{A partir de meados dos anos de 1980 ,}

o modelo consolidou-se e alguns efeitos perversos acentuaram-se

Somando-se ao caos anterior, dois fatos importantes foram responsáveis pelo agravamento da questão agrária na Amazônia a partir dos anos de 1980: as crises do petróleo e a prolongada recessão econômica do país.

Como decorrência das duas grandes crises do petróleo (1973 e 1979), quando o preço do petróleo árabe subiu enormemente e a energia se tornou cara, 
houve mudanças estruturais na economia do mundo ocidental. E na Amazônia as mudanças afetaram negativamente a já grave questão agrária, provocando o aumento de bolsões de pobreza. É que, a partir dos anos de 1980, os países centrais começaram a transferir empresas altamente consumidoras de energia e matéria-prima para os países periféricos, limitando-se a ficar com a transformação de produtos primários (ferro, alumínio, bauxita, celulose etc.) por eles importados, em produtos finais e, assim, poupando energia e livrando-se de danos ambientais. O governo brasileiro, desejoso de continuar crescendo, apesar da crise do petróleo, aceitou a transferência desses novos investimentos e alocou-os na Amazônia, especialmente no Pará. Assim, o país entrava numa armadilha que trouxe embutido um paradoxo: o crescimento econômico prosseguiria, mas através do endividamento, seja o externo - face aos compromissos com as infra-estruturas necessárias à instalação desses grandes projetos: portos, aeroportos, estradas, vilas residenciais etc.; seja o interno - devido aos subsídios concedidos aos empresários e aos recursos transferidos para as estatais que se incorporariam aos novos empreendimentos de forma consorciada com o capital estrangeiro. A simples elevação dos preços do petróleo já exigiria uma reorganização da economia mas, no caso do Brasil, isto não foi feito imediatamente. Ao contrário disso, para instalar essas indústrias, o país contraiu vultosos empréstimos, tentando dar conta das infra-estruturas para as novas usinas que deveriam ser construídas.

Inicia-se, então, a fase da mineração e da produção de carvão vegetal com madeiras da floresta nativa para abastecer as novas mineradoras da região. Assim, o gasto de energia e matéria-prima transferiu-se, definitivamente, dos países centrais para a periferia, enquanto nos países centrais o lucro foi potencializado pela transferência dos custos mais pesados para os países periféricos. Com esta e outras medidas eles superaram a crise do petróleo, enquanto a situação brasileira foi se agravando à medida que os juros dos empréstimos subiam. Após as crises do petróleo, o Brasil aumentou sua produção de alumínio em $770 \%$, a de celulose em $225 \%$, a de ferro em $196 \%{ }^{24}$, estando a maior parte dessas novas indústrias mineradoras e siderúrgicas de produtos primários (altamente consumidoras de energia) situadas na Amazônia, especialmente no Pará. Além da implantação das mineradoras e siderúrgicas de produtos semi-elaborados, o governo incentivou a exploração mineral em geral, visando ao aumento das exportações do saldo na balança comercial. Para tanto, alterou a legislação, permitindo a exploração em área indígena, o que gerou um sem-número de novos conflitos ${ }^{25}$.

Os empréstimos efetivados, por sua vez, converteram-se, (com as alterações sucessivas das taxas de juros) num perverso mecanismo de evasão de renda em favor dos países centrais. E, face à elevação do valor da dívida, as instituições financeiras internacionais (FMI principalmente) estabeleceram rígidas regras com vistas a estabilizar as finanças dos países endividados e, assim, verem ressarcidos os recursos emprestados. Esses fatores concorreram para o aguçamento da crise no Brasil. E, visando à estabilidade financeira o governo federal adotou políticas públicas de caráter neoliberal. Nos anos de 1990, os organismos multilaterais de 
financiamento entenderam que a transferência daqueles empreendimentos altamente consumidores de energia para os países periféricos havia aprofundado a crise destes e que, mais do que nunca, o equilíbrio das contas e o retorno à marcha para o desenvolvimento encontrava-se obstaculizada e que as políticas anteriores ("dos pacotes econômicos") de curto prazo, não seriam mais capazes de fazer os países retomarem as taxas de desenvolvimento das décadas anteriores.

Começam, então, a ser mais exigentes com os mesmos: a partir de então, não basta mais o equilíbrio do balanço de pagamentos; é preciso ter um supéravit primário capaz de garantir saldar as dívidas contraídas, estabilizar a moeda, vencendo a inflação histórica, reduzir os gastos sociais do governo, os investimentos governamentais, os custos da folha de pagamentos de salários, aposentadorias e pensões.

As políticas neoliberais de estabilização financeira adotadas pelo governo brasileiro eram recessivas e reduziram drasticamente os gastos em investimentos, nas políticas sociais e mesmo em investimentos produtivos. Assim, nos anos de 1980 e 1990, o país vivenciou uma dura fase de estagnação econômica, com enorme aumento do desemprego. Novamente, a Amazônia foi penalizada, pois a intensa migração de pessoas que nela buscavam melhores oportunidades de vida fez com que a população da região alcançasse ${ }^{26} 6.735 .307$ habitantes em 1980 e 10.029.351 habitantes em 1991. Nos anos de 1990, como decorrência de novas políticas, as correntes migratórias prosseguiram em direção à Amazônia, que chega ao ano $2000 \mathrm{com} 12.135 .442$ habitantes ${ }^{27}$. O crescimento deveu-se à migração desordenada de desempregados que vinham em busca de oportunidade de vida ou de trabalho na retirada de madeira ou garimpando em terras indígenas, ou ainda como peões em desmatamentos para criação de gado. Por sua vez, os novos empreendimentos mineradores provocaram o aumento das queimadas para a produção de carvão e a expulsão de posseiros naturais da região de suas terras ou de migrantes que haviam ocupado terras de projetos abandonados ou improdutivos.

Além do problema do baixo ou mesmo negativo crescimento do PIB (Produto Interno Bruto) na década de 1980, para fazer face às despesas os governos foram, gradativamente, diminuindo os investimentos em infra-estrutura e sociais, elevando os juros bancários na tentativa de sustar a inflação e, ao mesmo tempo, atrair recursos para pagamento da dívida pela venda de títulos da dívida pública remunerados a altas taxas de juros, ampliando assim a carga tributária no país. O resultado não podia ser pior: a recessão que já havia afligido o país na década de 1980 prolongou-se nos anos de 1990.

Esses fatores conjugados esgotaram os recursos públicos necessários para uma reorganização fundiária da Amazônia, para a implantação de varas judiciais, para a demarcação de terras indígenas, para a apuração de crimes os mais diversos ligados ao trabalho escravo, à pistolagem, à grilagem e outros que transformaram a Amazônia em área conflagrada. 


\section{Intensifica-se a mineração}

\section{e a extração de madeira em área indígena}

Como a atividade produtiva "de boa índole" ficou prejudicada pela prolongada recessão dos anos de 1980 e 1990, os governos dos estados da Amazônia tornaram-se tolerantes com a exploração madeireira, autorizada à larga e sem um processo de reflorestamento ou manejo florestal seriamente fiscalizado ou mesmo com a extração ilegal de madeiras ${ }^{28}$. A pauta de exportação do estado do Pará permite mostrar que as madeiras correspondem hoje a quase $20 \%$ (dados do primeiro semestre, quando as chuvas diminuem o corte das mesmas), alcançando mais do que isto durante o segundo semestre do ano, no "verão" amazônico. Daí porque os diversos governos têm sido tão tolerantes com o desmatamento. Consideram mais fácil continuar gerando receitas com atividades predatórias do que reorganizar um sistema produtivo perverso mas, de qualquer forma, já estruturado.

Produtos Exportados pelo Estado do Pará (jan.-jun. 2000)

\begin{tabular}{l|c|c}
\hline NOVOS: MINERAIS & & 77,78 \\
\hline TRADICIONAIS & 223.048 & 22,22 \\
\hline Madeira e pasta química de madeira & 184.646 & 18,40 \\
\hline Pimenta e dendê & 13.480 & 1,35 \\
\hline Castanha do Brasil & 4.452 & 0,44 \\
\hline Camarões congelados e peixes & 12.816 & 1,27 \\
\hline Palmito em conserva & 2.289 & 0,23 \\
\hline Móveis e artesanato de madeira & 1.801 & 0,18 \\
\hline Couros e peles & 1.727 & 0,18 \\
\hline Suco de frutas & 1.837 & 0,40 \\
\hline Outros & 4.015 & $\mathbf{1 0 0}$ \\
\hline TOTAL & $\mathbf{1 . 0 0 3 . 6 0 6}$ & 0,17 \\
\hline Fonte: Sistema Alce/ Secex/Fiepa/CIN & $30 / 7 / 2002$. & \\
\hline
\end{tabular}

Fonte: Sistema Alice/Secex/ Fiepa/CIN - 30/7/2002.

Mas não se pense que a situação não pode se agravar mais. Os indícios de que isto pode acontecer são evidentes, quando se analisa as mais recentes frentes de expansão dos negócios, lícitos ou ilícitos. Um fato desse agravamento é a extração de madeiras (especialmente do mogno) e de minérios na Terra do $\mathrm{Meio}^{29}$, especialmente em áreas indígenas. 
Nos últimos trinta anos, o comércio ilegal de madeira no Pará movimentou cerca de R\$ 10 bilhões, enriquecendo comerciantes que passaram a agir como se fossem os donos do estado e de suas florestas. A disputa por essa madeira alimenta boa parte das matanças que acontecem com freqüência no Pará. Mais de $80 \%$ da madeira exportada é esquentada com documentação falsa. Ela vinha saindo sem problemas pelos portos de Belém e Paranaguá (PR), até que o governo federal abriu os olhos e proibiu a exploração, transporte e comercialização do mogno. Os madeireiros foram bater na porta da Justiça Federal com liminares para garantir o embarque para o exterior. ( O Estado de S.Paulo. Caderno Nacional, Agência Estado 5/3/2005).

O mogno de origem ilegal, conforme revela levantamento feito pelo movimento ambientalista Greenpeace, é "legalizado" por meio do uso de documentos oficiais do Ibama fraudados por interessados. As madeireiras Peracchi, Tapajós Timber, Semasa, Madeireira MCP e Juary/ Jatobá controlam cerca de $80 \%$ das exportações paraenses. Já do lado dos importadores, $80 \%$ do comércio de mogno são controlados por apenas quatro empresas Aljoma Lumber, DLH Nordisk, J Gibson McIlvain Co. Ltd e Intercontinental Hardwoods. Não se trata, portanto, de um problema complexo ou, sequer, desconhecido...

Os "reis do mogno" e de outras espécies nobres de madeira atuam principalmente dentro de reservas indígenas, no sul e sudoeste do Pará- de preferência em Altamira e São Félix do Xingu. O caso mais grave é o da reserva Apyterewa, dos índios Parakanã, conforme o Relatório de Vigilância e Proteção das Terras Indígenas, da Funai. Diz o relatório que toda a extensão de Apyterewa está tomada por madeireiros, que freqüentam a aldeia e fornecem bebidas alcoólicas, armas e outras mercadorias aos índios. As matanças acontecem na surdina, e sequer chegam aos jornais do Pará e do resto do Brasil ${ }^{30}$.

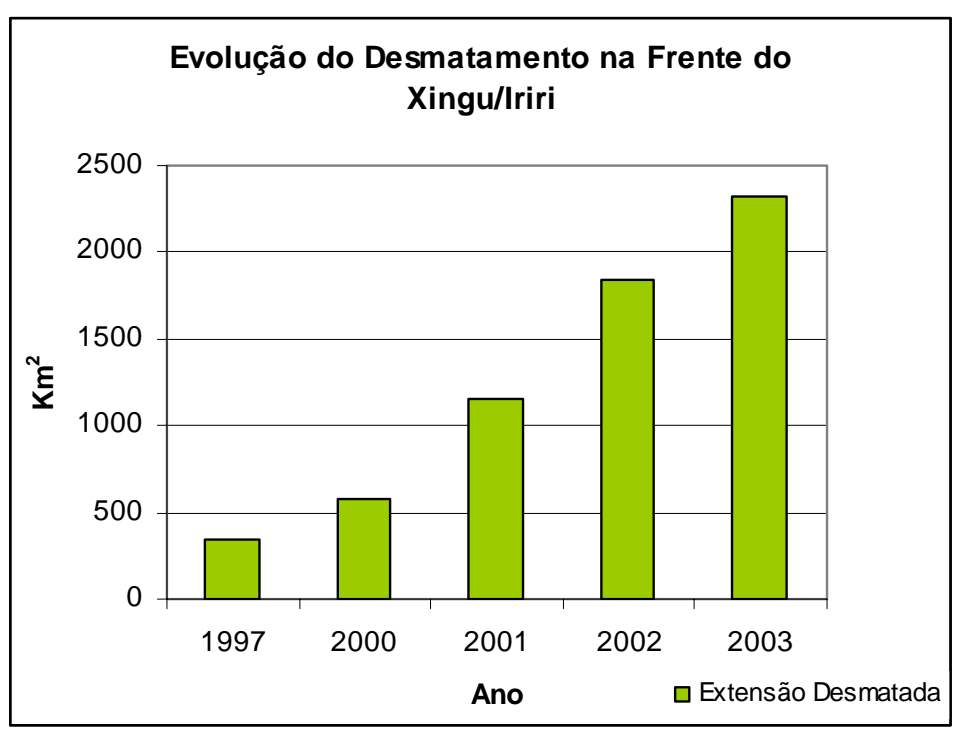

Desmatamento acumulado na Frente do Xingu/ Iriri, que se constitui numa parte da chamada Terra do Meio: $1997347 \mathrm{~km}^{2} ; 2000$ - $573 \mathrm{~km}^{2} ; 2001-1153 \mathrm{~km}^{2}$; $2002-1846 \mathrm{~km}^{2} ; 2002-2318 \mathrm{~km}^{2}$. (Fonte: www.dpi.inpe.br/prodes) $)^{31}$. 
Outro agravante é a expansão da soja no Pará. De acordo com a Embrapa, existem no Pará 20,7 milhões de hectares de áreas alteradas, onde o governo paraense pretendia incentivar a produção de grãos (arroz, milho e feijão), consorciada com a pecuária. No entanto, embora a soja tenha sido plantada inicialmente em áreas afetadas do nordeste paraense (a partir de 1997), hoje se processa em cima de áreas de florestas que são derrubadas ou queimadas no Baixo Amazonas; trata-se de sojicultores do centro-oeste que vêm direcionando seus negócios rumo ao norte e fixando-se em terras amazônicas próximas a Santarém. Por sua vez, o provável asfaltamento da rodovia Santarém-Cuiabá sem que qualquer planejamento sério sobre a questão social, ambiental e fundiária seja feito antecipadamente, pode reproduzir a selvageria da ocupação havida às margens de outras estradas federais nas décadas passadas, bem como a migração desordenada de desempregados para Roraima, instalando-se inclusive nas fronteiras, sobre terras dos índios Ianomami e outras frentes de expansão e conflito.

\section{Considerações finais}

É possível reverter essa situação? A história brasileira de exclusão social das classes pobres, aliada a outros fatores, permite considerar que, a curto e médio prazos, é ilusório esperar a reversão completa das situações existentes. Mas é possível minorar o impacto negativo de alguns graves problemas, recompor socialmente situações críticas de conflitos, reverter fraudes, sustar grilagens, fazer retornar ao patrimônio públicos enormes extensões de terra, ordenar minimamente a caótica ocupação dos espaços, diminuir o ritmo da devastação e evitar novos focos de tensão. Instrumentos legais e técnicos existem e estão disponíveis.

O Governo do estado do Pará vem depositando inteira confiança na aprovação de um projeto de Zoneamento Econômico Ecológico que tramita em regime de urgência na Assembléia Legislativa, na expectativa de equacionar boa parte das situações. Não devem os governos dos estados da região esperar tanto de um único instrumento e sequer esperar por ele para agir, seja ele o zoneamento, um cadastro único ou outro qualquer. Também não devem subestimar ou abandonar o potencial daqueles que as leis já lhes garantem e que, por isso, estão disponíveis para uso imediato.

O Zoneamento Econômico Ecológico ou o cadastro único é apenas um dos vários recursos passíveis de utilização, mas levará anos para ser elaborado e não terá impacto sobre a maior parte das questões sociais e jurídicas. Inúmeros problemas ambientais poderiam ser equacionados pelos estados sem esperar pelo zoneamento, tais como: a revisão de concessões, grilagens e fraudes de terra; a utilização de recursos técnicos e tecnológicos como imagens de satélite com vistas a sustar e a punir exemplarmente como a lei permite mas não se costuma fazer nos casos de desmatamento e garimpagem em áreas indígenas e de conservação ambiental; no desmatamento em encostas de montes, nascentes e margens de rios; agir em relação às grandes queimadas e a outros casos facilmente identificáveis. É possível, também, por meio de esforço político e jurídico, fazer 
a regularização fundiária de milhares de colonos assentados, de fato, há anos, mas fragilizados pela ausência de documentação; estabelecer manuais de procedimentos comuns mínimos para as ações federais, estaduais e municipais relativas à ocupação de terras; prosseguir na apuração de centenas de mortes nos campo, nos casos de pistolagem amplamente conhecidos e denunciados pela igreja, pela $\mathrm{OAB}$ e pelos sindicatos de trabalhadores rurais. Os instrumentos jurídicos e administrativos existentes permitem também rever e reverter as grandes concessões e vendas de terras que descumpriram os termos contratuais e utilizaram-nas indevidamente e dar curso a inúmeras outras providências, cujos efeitos começariam a ser percebidos imediatamente, mudando a impressão e o quadro real de barbárie, tolerância e impunidade no trato da questão regional amazônica. Finalmente, as sociedades amazônica e brasileira precisam discutir os destinos da região. É evidente que a mais exuberante e vasta floresta tropical do planeta não se constitui em área própria para reforma agrária. No entanto, que destinação dar aos milhões de hectares de terra já afetados ou degradados? Onde e como abrigar os colonos naturais e os migrantes? Como proteger índios e demais povos da floresta? Assim, simultaneamente, com ações de curto e médio prazos, essa questão - que é de fundo - deveria estar registrada permanentemente como uma prioridade na pauta das políticas nacionais e regionais.

\section{Notas}

l IBGE. Censo Agrícola, Rio de Janeiro, 1960.

2 Idem.

3 Ver, por exemplo, Fernando Henrique Cardoso e A. Falleto, Dependencia y desarrollo en América Latina. México, Siglo XXI, 1969, pp. 160 e 180. Ver também F. H. Cardoso, "Notas sobre o estado atual dos estudos sobre dependência", Cadernos Cebrap, n. 11, 1973, p. 63.

4 Relatório do Ipea publicado nos anos de 1980 já denunciava a fraude e a má aplicação de recursos financiados pela Sudam, vícios que persistem até os dias atuais. Embora inúmeras denúncias apuradas posteriormente tenham comprovado sobejamente os fatos, seus autores continuam protegidos pelas saídas que a legislação brasileira possibilita em relação aos autores de corrupção e outros crimes de "colarinho branco". Às vezes ficam presos por mais ou menos 48 horas; é o tempo suficiente para seus advogados impetrarem um habeas corpuse libertarem os acusados por tempo indeterminado. Certas fraudes e processos de vários tipos tramitam na Justiça por mais de vinte anos. Os acusados que foram condenados a ressarcir os valores à Sudam fizeram-no sem reajuste ou multa e, por isto, a preços defasados e simbólicos. Ver Instituto de Planejamento Econômico e Social (Ipea), Avaliação dos incentivos fiscais da Amazônia, Brasília, 1985.

5 Terra devoluta são terras públicas que, não sendo próprias, nem estando destinadas a nenhum uso público municipal, estadual, federal, não se incorporaram ao domínio privado na forma e nas condições legalmente previstas (ver o artigo 5 do Decreto-Lei no 9760 , de 5/9/1946). 
6 Refere-se à Amazônia clássica ou geográfica (Acre, Amazonas, Amapá, Pará, Roraima, Rondônia e Tocantins, este criado em 1991; a população corresponde àquela que habitava a área desmembrada para formar aquele estado). IBGE, Censos Demográficos, Rio de Janeiro, 1960-1970.

7 Gerdelina e Leonel Marochi, Banco Denasa de Investimentos, Jari Florestal, Cia de Terras Mata Geral, Agropastoril Rio Dourado, Nicobram Adm. Agrop. Ltda, Cia Vale do Rio Cristalino, Grupo Aquiqui. Conforme Instituto do Desenvolvimento Econômico Social do Pará (Idesp), Revista Pará Desenvolvimento, no 18, Belém, 1986, p. 51.

8 Ação discriminatória é o trabalho realizado por órgão fundiário com vistas a identificar e a separar a terra pública da terra privada. Realiza-se com trabalho de campo, geralmente no segundo semestre do ano, tempo em que as chuvas diminuem na Amazônia. Uma operação desse tipo pode demorar até noventa dias, dependendo da área, e envolve despesas consideráveis.

9 Conforme estabelece o artigo 98 do Estatuto da Terra, lei federal no 4504, que garante a terra através do usucapião simples com dez anos de moradia ou o usucapião especial - lei federal $n^{0} 6969$, de 10/12/81, com moradia de cinco anos sem interrupção ou contestação.

10 Ver por exemplo, Isto É, 20 mar. 2005, p. 37 e ss., ao tratar da legalização de terras griladas por madeireiros.

11 Isto É, 2 mar. 2005, p. 38. Ver também Jornal O Liberal, Belém, 10 mar. 2005, p. 5, só para mencionar três denúncias recentes.

12 Max Weber, Le savant et le politique, Paris, Plon, 1959, pp. 100-101.

13 Conforme Ministério da Fazenda (Seef), Comércio Exterior do Brasil - 1957-1958 (Rio de Janeiro, 1959) e dados fornecidos pelo Banco do Brasil (Cacex). Tabela extraída de Basa e UFPA. Desenvolvimento econômico da Amazônia, Belém, 1967, p.233.

14 Ver Ipea, Avaliação dos incentivos fiscais na Amazônia, Brasília, 1985.

15 São justamente os grandes produtores nacionais de soja instalados na Amazônia que, aliados ou não a políticos, vêm fazendo pressão junto ao Governo Federal em favor do asfaltamento da Cuiabá-Santarém e demonstrando ignorar os possíveis efeitos perversos do mesmo ou discutindo medidas a tomar para evitá-los.

16 Terras federais ou federalizadas sob as seguintes responsabilidades: Incra (43\%), dois grupos executivos que o governo federal criou nos anos de 1970 para tentar solucionar os já freqüentes conflitos de terra; Getat, na região do Araguaia-Tocantins e Gebam, margem esquerda do Amazonas, no oeste do Pará (14\%); outras destinações como Funai, Área de Fronteiras Federais e Aeronáutica completavam o restante. Fonte: Instituto de Terras do Pará (Iterpa).

17 Cf. artigo $1^{\circ}$ do referido Decreto-Lei $1.164\left(1^{\circ} / 4 / 1971\right)$ as áreas confiscadas situam-se na faixa de $100 \mathrm{~km}$ de cada lado das margens das seguintes rodovias construídas ou em projeto: Transamazônica, BR-317, BR-319, BR-236, BR-406, BR-174, BR401, BR-364, BR-156, BR-080, BR-153, BR-010 e BR-070. O decreto n⿳⺈ 1.164 foi completado posteriormente por outros que o reforçam, estendem seus efeitos ou o explicitam, como o Decreto-lei no 1.234 , de 30/10/1972, a Lei no 5.917 , de 10/9/ 1973 e o Decreto-Lei n ${ }^{\circ} 1.473$, de 13/7/1976).

18 Alguns dos projetos de colonização oficial foram instalados em cima de terras indígenas, aumentando as tensões e criando novos conflitos. 
19 Eleres Paraguassu, Patologia fndiária, Belém, Jornal O Liberal, Caderno de Atualidades, 6/3/2005, p. 8.

20 Grupo Executivo de Terras do Baixo Amazonas - criado durante a ditadura para, supostamente, resolver problemas fundiários graves no noroeste paraense.

21 Grupo Executivo de Terras Araguaia-Tocantins - criado durante a ditadura para, supostamente, resolver conflitos agrários e questões fundiárias da zona situada entre os dois rios do mesmo nome (Pará).

22 Caso que repercutiu na imprensa internacional. A freira defendia a manutenção de um movimento de pequenos coletores extrativistas de uma reserva ecológica e foi morta em fevereiro de 2005 por pistoleiros a mando de fazendeiros, no município de Anapu, Pará.

23 Pessoas que recrutam trabalhadores desempregados, geralmente no nordeste do Brasil, trazendo-os para a região.

24 Fonte: Eletrobrás. Departamento de Distribuição e Conservação de Energia. Política industrial e energia 15 anos após o primeiro choque do petróleo, Rio de Janeiro, 1990.

$25 \mathrm{Na}$ década de 1980, no Pará e Amapá, quinze multinacionais, oito estatais, dezessete empresas privadas nacionais, treze empresas individuais e doze grupos de capital não identificado tinham interesse na exploração mineral em terras indígenas, quase todas elas no Pará. Fonte: Pesquisa feita pela Coordenação Nacional de Geólogos (Conage) e Centro Ecumênico de Documentação e Informação (Cedi) em 1985. Dados e texto apresentados na Revista Pau Brasil, São Paulo, Daee, n. 10, ano 2, fev. 1986.

26 Refere-se‘à Amazônia clássica ou geográfica (Acre, Amazonas, Amapá, Pará, Roraima, Rondônia e Tocantins, criado em 1991; a população corresponde àquela que habitava a área desmembrada para formar aquele estado).

27 IBGE, Censos Demográficos, Rio de Janeiro, 1980, 1991 e 2000.

28 Duas semanas antes do assassinato da Irmã Dorothy Stang, os jornais locais divulgaram que o governador do estado do Pará estava acompanhando uma comitiva de madeireiros a Brasília, para reivindicar junto ao Ibama a liberação da exploração madeireira em áreas e em quantidades que o Ibama havia vetado. A repercussão do assassinato da freira sustou a possível liberação que o Governo do Estado estava pleiteando.

29 Alumínio, ferro, hematita, caulim, bauxita, ouro, silício, manganês.

30 Enorme área de terra situada no sul do Pará, sendo uma das áreas mais ricas em madeiras e minérios; nela ficam situadas várias etnias indígenas. Caracteriza-se pela enorme riqueza natural e pela barbárie nas relações sociais: campeia aí o trabalho escravo, a super-exploração do trabalho, a garimpagem irregular, o contrabando, a violência e o conflito.

31 Recentemente, foi expedido decreto regularizando essa terra indígena em 773 mil ha, área que ficou reduzida de pelo menos 300 mil ha que a área original.

32 Relatório Rede Geoma, 2004, p. 4.

\section{Referências}

BASA / UFPa. Desenvolvimento Econômico da Amazônia. Belém, 1967. 
CARDOSO, Fernando Henrique e FALETTO, A. Dependencia y desarrollo en América Latina. México, Siglo XXI, 1969.

CARDOSO, F. H. "Notas sobre o estado atual dos estudos sobre dependência". Cadernos Cebrap, n. 11, 1973.

ELETROBRÁS. Departamento de Distribuição e Conservação de Energia. Política industrial e energia 15 anos após o primeiro choque do petróleo. Rio de Janeiro, 1990.

IBGE. Censo Agrícola. Rio de Janeiro, 1960.

. Censo Demográfico. Rio de Janeiro, 1960.

. Censo Demográfico. Rio de Janeiro, 1970.

. Censo Demográfico. Rio de Janeiro, 1980.

. Censo Demográfico. Rio de Janeiro, 1991

. Censo Demográfico. Rio de Janeiro, 2000.

IPEA. Avaliação dos incentivos fiscais da Amazônia. Brasília, 1985.

IDESP. Revista Pará Desenvolvimento, n. 18, Belém, 1986.

ISTO É, 20 mar. 2005.

PARAGUASSU, Eleres. Patologia fundiária. Belém, Jornal O Liberal, Caderno de Atualidades, 6 mar. 2005, p. 8.

WEBER, Max. Le savant et le politique. Paris, Plon, 1959.

RESUMO - O ESTUDO faz um histórico da questão agrária amazônica, enfatizando os problemas sociais e fundiários criados durante a ditadura (transferência da terra pública para grupos privados, concessões e favorecimentos, grilagem, fraude, trabalho escravo, pistolagem etc) e os novos que a eles se somaram nas décadas seguintes e que, como os anteriores, igualmente não foram resolvidos. Procura mostrar a gravidade da questão agrária amazônica e o caos fundiário nela instaurado.

Palavras-chave: Pará; questão agrária; pistolagem.

ABstaCT-THIS STUDY makes a historical review of the Amazon agrarian issue, emphasizing social and land problems during the dictatorial years (conveyancing of public land to private groups, concessions and favouring, "grilagem" (illegal occupancy of land property) fraud, slavery, gunmen etc) as well as in the decades to come, problems which, as the ones before, were never solved. It intends to show the seriousness of the Amazon agrarian issue and the land chaos set up ever since.

Key-words: Pará; agrarian issue; gunmen.

Violeta Refkalefsky Loureiro é doutora em Sociologia pela Universidade de Paris III e professora da Universidade Federal do Pará. @ - violeta.loureiro@ig.com.br

Loureiro Jax Nildo Aragão Pinto é mestre em Sociologia pela UFPA, professor do Instituto de Estudos Superiores da Amazônia e coordenador da Comissão Pastoral da Terra - Pará. @ - cptpa@conectus.com.br

Recebido em 2/3/2005 e aceito em 18/4/2005. 